\title{
Discourses of Political Policing in Post-patten Northern Ireland
}

\author{
Kevin Hearty ${ }^{1}$
}

Published online: 25 October 2017

(C) The Author(s) 2017. This article is an open access publication

\begin{abstract}
This article critically examines discourses of political policing in contemporary Northern Ireland (NI). Recognising the post-conflict and post-reform climate that policing now occurs within, it argues that these environmental factors have conditioned discourses of policing that are directly tied to how legitimate political opposition to the political status quo in post-Good Friday Agreement (GFA) NI is policed. The article asserts that political policing discourses have taken a new trajectory that departs from traditional ethno-nationalist interpretations of the issue to instead reflect a broader structuralist interpretation of state-police power relations. It concludes with the argument that political policing discourses have evolved to reflect common class-based disillusionment with the post-GFA state across the political divide that sees the matter rooted in police protection of a system of devolved governance that has failed to tackle structural exclusion and socio-economic deprivation.
\end{abstract}

\section{Introduction}

Critical criminology has long critiqued state-police power relations (Albrecht and Green 1977; Scraton 2007). Its core assertion is that policing represents the means by which existing power relations and structures are protected from fundamental challenge by the body politic (Hepburn 1977). Although this applies to all societies, it takes on heightened relevance in societies like the North of Ireland where the state itself has been historically contested. ${ }^{1}$ From its inception as a colonial product of partition, the Northern Ireland (NI)

1 The terms North of Ireland, six counties and Northern Ireland are used interchangeably throughout the article.

Kevin Hearty

k.hearty@qub.ac.uk

1 School of Law and the Senator George J. Mitchell Institute for Global Peace, Justice and Security, Queen's University Belfast, Belfast BT7 1NN, UK 
state witnessed policing that protected the political, social and cultural hegemony of the Protestant bloc in the territory who paid ethno-nationalist allegiance to Britain over the minority, mainly Catholic, Nationalist community who had a desire for Irish national selfdetermination (Mac Ionnrachtaigh 2013). A system of 'divided society' policing took root, whereby biased law enforcement by the Protestant dominated Royal Ulster Constabulary (RUC), under the direction of an exclusivist Unionist administration, privileged the dominant community and disadvantaged the minority community (Weitzer 1995: 5). Although by no means homogenous, the Protestant bloc managed to unite the upper and middle classes with working-class communities - the latter self-identifying today as the Protestant/Unionist/Loyalist (PUL) community (McVeigh 2015)—under a common ethnonationalist banner (Kelly 2012), allowing ethno-nationalism to be the main fault line for 'divided society' policing. This is not to suggest there was not an underlying socioeconomic dimension to policing too. Political violence largely bypassed more affluent middle-class 'mixed' areas, leaving the segregated working-class areas to bear the brunt of it. Middle-class areas therefore experienced more normalised policing while working-class communities experienced more aggressive policing, ranging from outright counter-insurgency to violent public order policing (Brewer and Magee 1991). Indeed, working-class Protestants did experience political policing from the RUC during the conflict (McVeigh 1994), particularly on occasions when they staged political protest or expressed discontent. However, as the RUC shared an ethno-nationalist allegiance and pro-state ideology with this community, it was the minority Nationalist community, and working-class elements of that community especially, that was primarily politically policed as a 'suspect community'.

Accordingly, policing charted a convoluted trajectory in the six counties; from prepartition days of upholding 'planter' privilege, to safeguarding Protestant supremacy in the pre-conflict state, to counter-insurgency and 'suspect community' policing of Nationalists (McGarry and O'Leary 1999; Ellison and Smyth 2000). As conflict lessened with the onset of the peace process and the signing of the consociational Good Friday Agreement (GFA), police reform-known locally as the Patten process-became central to conflict resolution by redressing imbalance in religious composition, neutralising police symbolism and establishing new accountability mechanisms (Murphy 2013; Mulcahy 2013). Demonstrating the link between policing and the state, the St Andrew's Agreement attempted to resolve residual post-GFA political disagreement by offering restoration of the then suspended devolved governmental institutions in return for formal endorsement of post-Patten policing and criminal justice by all governmental parties. As a result, Sinn Fein committed to 'critical engagement' with post-Patten policing, couching its decision in discourses on furthering change from within, increasing accountability and preventing future political policing (Hearty 2016).

The aim of this article, however, is not to revisit well covered academic debates on 'divided society' policing in NI or Patten reform (Weitzer 1995; Ellison and Smyth 2000; O'Rawe 2010; Mulcahy 2013; Murphy 2013). It aims instead to stimulate a new critical examination of political policing discourses in NI that departs from the traditional ethnonationalist 'divided society' paradigm. Rooted in critical criminology, it proposes a more nuanced understanding of critical views on policing that link it to disillusionment with the post-GFA state and Sinn Fein 'critical engagement'. In particular, it identifies commonality and divergence in discourses constructed and circulated by those 'left behind' by transition that transcend traditional communal understandings of policing in the six counties. Arguing that the most noteworthy common denominator is a structuralist understanding that links policing to the protection of dominant state interests (Brogden 1982: 12), the article examines critical narratives based on lived experience of how legitimate political 
opposition to and discontent with the post-GFA state is policed in a post-conflict, postreform environment. These narratives have been gleaned from analysis of extensive media and social media coverage of high-profile incidents and from original interview data. ${ }^{2}$ In using these sources, the article has deliberately drawn from the most critical voices. However, as Phil Scraton (2007: 15) notes, it is only by engaging with these voices that official discourse can be adequately critiqued. The necessity to so challenge official discourse in post-Patten NI can be found in Topping's (2015: 151) admission that 'official accounts of policing are but one version of reality'. In locating the matter within an examination of the wider post-GFA state, the article accepts Robert Reiner's (2010: 4) premise that policing is a process that extends beyond the organisational body known as 'the police'. While not seeking to deny that all policing is inherently political in certain ways (Brodeur 1982; Scraton 1985; Reiner 2010: 33; Neocleous 2000, 2014), this article employs the term 'political policing' to refer to the Police Service of Northern Ireland (PSNI) and criminal justice system response to legitimate political activity in post-GFA NI.

\section{The Post-GFA State}

In his critique of policing Neocleous (2000) argues that the state-police legitimacy nexus manifests through police regulation of society. Essentially, the police legislatively and administratively regulate those without power and access to resources for the protection of those who do. This politico-legal coercion through the 'rule of law' sustains the socioeconomic coercion dispensed by other arms of the state (Neocleous 2014: 30). On this basis, state-police legitimacy can be seen as acceptance of the existing social order and the preparedness to be regulated if/where necessary within this framework. If one refuses to subscribe to their purported position within the existing social order they will, as a natural consequence, refuse to be regulated by those safeguarding it. Here neither the state nor the police have been granted legitimacy. Given this, securing consent for reformed policing is contingent upon securing consent for the socio-political order of the post-conflict state. If there are underlying legitimacy problems with the post-GFA state and/or the GFA itself, these will invariably impact on police legitimacy.

The GFA introduced a devolved consociational administration to the North of Ireland premised on powersharing between those of different political persuasions. Although Sinn Fein accepted this arrangement, for some Irish republicans it was problematic given that the GFA failed to offer national self-determination, stipulating instead that this could only be secured with the consent of the majority of people on the island. This created an ideological rejection of post-GFA structures as a neo-colonial administration that sustains 'British rule' in Ireland, with the consequent logic being that post-reform policing is 'British policing' that upholds this entity (Hearty 2016). While some have articulated their irredentist aims through continued spoiler violence (Bryce 2013), others have expressed disagreement through legitimate political activity. The consociational nature of the GFA also witnessed the proclivity of opposing groups weighing up their position relative to that

\footnotetext{
230 semi-structured interviews were conducted with actors across the spectrum in modern Irish republicanism between April and November 2013 as part of the author's Ph.D. fieldwork. Interviewees are identified herein only by a random letter. No original qualitative data was available from the PUL community. This admittedly skews the data in favour of the Irish republican discourse slightly. Nonetheless the PUL 'critical voice' has been incorporated into this paper's analysis via open access sources like newspapers and social media, where the PUL community have articulated their worldview on policing. The conclusions proffered in the paper are therefore based on qualitative, albeit different, data from the PUL community too.
} 
of the 'other' being carried over from conflict into transition. That has created tension between how the GFA is perceived by 'power holding' and 'power seeking' groups (MacGinty and du Troit 2007). In terms of the working-class PUL outlook, this has conditioned views of the post-GFA state in two ways; the neo-colonial dimension that relates it to the status of the ethno-nationalist 'other' and their subordinate class relation to political unionism (McVeigh 2015: 122). This has framed the peace process in terms of 'winners' and 'losers', with both the ethno-national 'other' and class 'other' being 'winners' while they remain 'losers' (McVeigh 2015: 145). Permeating this 'winner-loser' logic is an ideological rebuke of Sinn Fein involvement in post-reform policing (Nolan et al. 2014: 95), seen as a further takeover of the post-conflict state. Accordingly, competing frameworks of rejection predicated on notions of too little change versus too much change in the nature of the post-GFA state and reformed policing are discernible. These frameworks exist due to ideological interplay with Sinn Fein's changing policing 'from within' discourse (Hearty 2016); one arguing that aesthetic and religious compositional changes do not change the fundamental role or nature of policing, the other asserting that changes couched in equality discourse are an extension of war by other means by politically emboldened Irish republicans.

Ideological rejection is, however, only one aspect of the post-GFA state legitimacy deficit. While the post-GFA state has been keen to promote its new image as a politically inclusive polity that values civil and political rights, this has not, as Tomlinson (2012) notes, involved seriously tackling socio-economic deprivation. This reflects the model of consociationalism enshrined in the GFA. While this model accommodates a dispersal of socio-political power across ethno-nationalist lines (Brewer 2010), that does not automatically translate into wholesale dispersal across class lines. In practice, this means the political representatives of the formerly excluded minority have been elevated from a position of relative powerlessness into the system of governance but the most marginalised sections of that same constituency that lie outside formal party politics have not. A discursive symbiosis therefore exists between the position of Sinn Fein and that of those 'left behind' in critical narratives of the post-GFA state. Anti-GFA Irish republicans argue that while Sinn Fein has been co-opted into the neo-liberal state through state-funded community sector jobs and government positions (Hearty 2016), others in their community remain in the same socio-economic deprivation experienced during the conflict. For the PUL community, it means that the 'other' has managed to convert social capital accumulated during the conflict into post-conflict political capital, with the result that they now walk the corridors of power while PUL communities remain reliant on middle-class parties to defend their interests (Shirlow 2012). With the post-GFA state failing to tackle socioeconomic exclusion while at the same time being mired in a number of corruption scandals, both constituencies might see merit in Neocleous' (2014) argument that switching the label 'war' for 'peace' in a neo-liberal state simply masks, rather than changes, the continuing protection of capital. Because notions of inclusion and exclusion, as interpreted through policing, adhere to existing ideological premises (Loader and Mulcahy 2003: 39), this means in the six counties views primarily coalesce around pre-existing ethno-nationalist tinted ideological outlooks rather than a new class-based one.

Failure to eradicate the structural causes of socio-economic deprivation breeds a postconflict environment conducive to continued rejection of the political system that presides over such inequality (Steenkamp 2005) and the reformed police force defending this systematic exclusion (Goldsmith 2005). These are reflected in discourses that depart somewhat from the ideologised frameworks identified above by reflecting common classbased positions. For working-class PUL communities there are protests that socio- 
economic exclusion has left them under-represented at the highest levels of political office, business and in universities (Long 2015b). Likewise, it has allowed Irish republicans to venture beyond ideological rejection of 'British rule' and 'British policing' in their critiques of the post-GFA state:

West Belfast has the highest rate of child poverty in the United Kingdom. Sinn Fein has been in control of it now for 30 years. What the hell are they doing? They're going to build a football stadium. You know circuses. I am of the opinion on that basis that Sinn Fein should be asked the solid questions not whether we want to go back to war or not, as should the DUP and the entire Northern structures asked the real questions but, having said that, it is within those real questions that we also address the question of policing (Interviewee G, July 2013).

The convergence of the arguments above on the common ground of continued socioeconomic exclusion exposes the failure of the post-GFA state to deliver on promises made during the onset of the peace process. The GFA was sold to war-weary communities through a neoliberal 'conspiracy of hope' that tied peace to prosperity through multinational capitalism, foreign investment and the free market (Coulter 2014). Despite the promise of a 'peace dividend', continuing structural exclusion means that 'the very same districts that suffered the brunt of violence from 1969 onwards remain at the bottom in poverty, unemployment and social deprivation' (Kelly 2012). Instead of bringing prosperity, the post-GFA 'peace dividend' has left $23 \%$ of children living in child poverty (BBC 2015) and 42\% of households in fuel poverty (Press TV 2015).

The upshot of this is class-based resentment that has transcended the political divide:

Many [Irish republicans] who fought in the democratic and the armed struggle perceive themselves to be no better off. The economic and social system we have has consigned them to continued welfare, poor education, and now austerity. Yet their opposition to this is described as "dissidence" and dismissed... the sense in the loyalist community is that they actually lost... to everybody despite unwavering loyalty to the regime, even to those who challenged it by force. The anger in loyalist communities is fuelled by them still not having the price of a loaf and seeing Martin McGuinness [Sinn Fein] up running the country (Devlin-Mc Aliskey 2016).

\section{Labelling 'Dissidence'}

How this 'dissidence' is labelled remains key to understanding discourses of post-Patten political policing. By its very nature, political policing wilfully fails to differentiate between legitimate political opposition to the state and the advocating of violence and disorder (Brodeur 1982). In the North of Ireland this has led to any opposition to the postGFA dispensation being falsely conflated with support for spoiler violence or the public disorder that periodically mars political protests. The mere act of articulating 'dissidence' that can sometimes, yet not exclusively, be expressed through violence risks incurring the label 'anti-peace' - and, in the case of Irish republicans, the pejorative 'dissident' tag (Kelly 2012; Bryce 2013). The broad-brush application of such labels to marginalised groups is integral to how the state controls and manages political dissent (Scraton 2007). Once labelling has successfully 'othered' those with 'dissidence' as a political and/or criminal danger, the state has greater latitude in terms of how it polices them (Hudson 2003). 
Some Irish republicans argue that the ramification of such labelling is the reduction of their legitimate class-based critique of the post-GFA state to support for violence. The reality is, of course, that one can legitimately oppose the post-GFA dispensation on any number of grounds without supporting violence:

Anyone who has a different political belief, people who are seen to be not supporting Stormont [devolved administration] and the difficult terminology that's used out there; 'pseudo republicans', 'dissidents', 'anti-peace process people' all getting mixed up for those who are politically policing rather than it being what it is. A political, well thought-out understanding of what it is about: 'No we don't accept this... neoliberal agenda that you are operating here' (Interviewee J October 2013).

Even though criticising the post-GFA state does not equate support for spoiler violence, a contrived false conflation has nonetheless been useful in muting leftist criticism of the post-GFA government (Kelly 2012). Accordingly, one Irish republican criticised spoiler violence on the basis that 'it allows the British to say that opposition or a critique of the current process is really promoting that type of action', with the consequence that it is:

Frightening off people who otherwise might be willing, and many of them would be willing, to say that while we don't want to go back to war we still have grave reservations about what Nelson McCausland is doing over housing, what Jim Alister has done to former prisoners, to the idea that the department at Stormont would not build a motorway from Derry to Dublin (Interviewee G, July 2013).

For disillusioned PUL critics of the post-GFA state, labelling has falsely conflated their opposition with support for the disorder and violence associated with the Belfast flag protests. Mulvenna (2015: 162) argues that the protests were ultimately the manifestation of the growing disconnect between those who have profited in the 'new' Belfast and those who have not. Although several protest events were peaceful, media attention was confined to those marred by violence (Nolan et al. 2014). In the aftermath of the episode, PUL communities have been labelled the 'undesirables' in the 'new Northern Ireland' (Long 2015a).

Labelling and the false conflation of legitimate political opposition with support for violence and/or disorder have cultivated post-GFA 'moral panic' (Hall et al. 1978). Consequently, this permits a policing 'clampdown' on the 'anti-peace' problem group that will protect the rest of peace loving society (Brogden 1982: 6). While this is often couched in terms of protecting the moral fabric of society from the threat of those 'othered' in mainstream discourse (Choongh 1997: 3), in reality it is often predicated on penalising unpopular groups deemed anti-state or anti-police (Kettle 1980). The cumulative effect of this is that merely possessing 'dissidence', rather than violently or illegally expressing it, can see one 'labelled as being anti-peace process, a dissident, a conflict junkie and you then find yourself becoming a target of political policing, stop and searches, house raids and harassment' (Eirigi Newry 2011). To dissent, then, is to leave oneself open to being labelled 'anti-peace' or 'anti-police', which in turn leaves oneself open to political policing. Even if you are not bombing the police or rioting on the streets of Belfast, the mere virtue of holding 'dissidence' leaves you prone to being policed as if you were.

This dynamic positions all opponents of the post-GFA state as 'outsider', thus opening them up for sanction regardless of the legality or illegality of their 'dissidence' (Becker 1963). In turn, this allows targeted political policing to separate supposedly dangerous 'outsiders' from the rest of peace-loving society: 
Instead of using a hammer to crack a nut, as in wide spread oppression and targeting of the Nationalist community, the tactics are more intelligent from the PSNI's point of view whereby republicans specifically are targeted and they're trying to be separated from the community as in 'look at them big scary republicans, so we'll stop and search republicans and target republicans' and from there try and sort of separate them from the Nationalist community (Interviewee F, September 2013).

Those who disagree with the post-GFA state thus become 'police property' (Cray 1972) to be rigorously policed in furtherance of protecting the respectable elements of post-GFA society. In accordance with this, political policing in post-conflict NI assumes a social disciplinary function whereby it is less connected to crime control and more reflective of police contempt for the behaviour, beliefs or mere existence of those that challenge respectable notions of normality (Choongh 1997: 223). The transformation of those aggrieved at missing out on the 'peace dividend' into 'police property' substantiates Scraton's (2007: 15) argument that 'otherness' fluctuates between mere invisibility to those in power and bearing the rough edge of state intervention. This means that those initially overlooked by a Stormont administration championing neoliberalism over addressing socio-economic exclusion can come to find themselves politically policed if and when they express their dissatisfaction with this.

\section{The 'PSNI/RUC'}

Perceptions of post-reform policing are dependent on group positions and views of the post-reform political terrain (Jackson and Lyon 2001). Accordingly, there will be differences in the political policing discourses proffered by anti-GFA Irish republicans and PUL communities that reflect different ideological views borne from Sinn Fein 'critical engagement' and different lived experiences of post-Patten policing.

The Irish republican referral to the 'PSNI/RUC' encapsulates their view that there has been no substantive change to policing despite an increased Catholic/Nationalist presence because the political function and methods of 'British policing' in the North of Ireland have remained the same (Hearty 2016). This has been constructed from criticism of certain aspects of the Patten reform process and lived experience of 'high policing' (Brodeur 2007) whereby unaccountable intelligence agencies are politically policing Irish republican opponents of the post-GFA state. While this may reflect a broader 'War on Terror' security climate that has seen a general policing turn to the 'national security state' (McLaughlin 2007: 100), in the particular localised context of NI the historic trend has been that antiterror provisions allow intelligence agencies and/or the police to punish people on the basis of some assumed association with violent groups rather than targeting them because of any breach of criminal law (Blackbourn 2013). This has led to claims that intelligence agencies are cynically using intelligence-based 'evidence' to implement polices of 'internment by remand' and 'administrative detention' that remove legitimate political activists without having to process them through open court (Interviewee I, September 2013). Such concerns have been amplified by the impotency of post-Patten accountability mechanisms in regulating the conduct of MI5 who now lead 'national security' policing in NI (Committee on the Administration of Justice 2012b). That Irish republicans experience 'high policing' more than PUL communities indicates how reformed policing will continue channelling the bulk of its political policing efforts towards those deemed the most serious threat to the state (Mulcahy 2013: 194). This has been acknowledged by Irish republicans involved in 
legitimate political activity who recognise that the nature of their core ideological goal places them in de facto opposition to the post-GFA state and its policing apparatus (Jackson 2007). The drawback of this is that it perpetuates the narrative that policing remains sectarian and/or political (O'Rawe 2010: 107). The intertwining of these observations in the Irish republican discourse can be seen in the following remarks:

Because Barra McGrory who happened to be a supporter of Nationalists is now the head of PPS [Public Prosecution Service] does not change a thing. Because a Catholic is the Attorney General does not change a thing. We still have special trials, we still have extremely lengthy remand periods for republicans, we still have special prisons, still have special laws, we still have special detentions... nothing has changed (Interviewee A, July 2013).

The misuse of stop and search provisions also shapes their policing discourse. Indeed, stop and search powers under the Terrorism Act (TACT) and the Justice and Security (Northern Ireland) Act 2007 have been most heavily exercised by the PSNI in working-class Nationalist areas. Areas like Ardoyne (Belfast Live 2015) and Newry (Irish Republican News 2016) have witnessed thousands of stop and search operations and hundreds of house raids in recent years with few charges, and even fewer convictions, resulting. This use of stop and search as a 'disruption tactic' has been condemned because it has a proven propensity to degenerate into the targeted harassment of legitimate political activists (Committee on the Administration of Justice 2012a). Rather than being used to disrupt spoiler violence, stop and search can entail harassing those engaged in legitimate political activity:

You can see with stop and search alone political policing is still alive. We've people on leaflet runs getting stopped and searched. I mean it is madness like, but it all is intelligence gathering on ourselves, and if it wasn't a political police force then why is this happening. That's the question you have to ask. So it is happening so you have to go 'well there's a political aspect to this happening'. Why would you stop and search somebody handing out a leaflet? (Interviewee F, September 2013).

If the basis for stop and search operations is problematic, so too is police conduct during them. Claims of PSNI aggression during stop and search encounters persist (The Plough and The Stars 2016). Conduct of this nature may be reflective of Satnam Choongh's (1997: 4) observation that police interaction with certain groups can mirror police perception of the worth or worthlessness of such groups. PSNI aggression may then reflect their continued distaste for anti-GFA Irish republicans and their political activities. Anti-GFA republicans thus contextualise experiences of post-Patten political policing within the historic landscape of political policing in the six counties, meaning that their communities are 'facing daily harassment, intimidation, home invasions and militarisation of their area by a sectarian force continuing the tactics of harassment, intimidation and torture that their forerunners in the RUC also implemented' (Irish Republican News 2015).

\section{The 'PSNIRA'}

As a constituent of the all-class alliance Protestant bloc that dominated the 'divided society' of NI (Kelly 2012), PUL communities had a more cordial relationship with policing than Irish republicans. Relations were, however, strained at certain key historical junctures when the RUC were deemed to have violated tribal loyalty (Murphy 2013: 56). 
Criticism that was largely muted during the conflict for fear of offering succour to Irish republicans is now openly expressed (O'Rawe 2010: 108; Mulcahy 2013: 90). This reflects the changed PUL worldview in the post-GFA state whereby a Protestant state and a Protestant police force have been unceremoniously reformed to appease Sinn Fein.

The PUL narrative is premised on the 'low policing' of parades and protests that represents a 'forceful reaction to conspicuous signs of disorder whether criminal or not' (Brodeur 1982). There is a class dimension to this given that violence and disorder stemming from such activity is most heavily concentrated in deprived areas synonymous with past violence (McDowell et al. 2015). The most useful lens for viewing this through is the Belfast flag protests. 306 people were convicted for protest related activity, including 37 who received custodial sentences (Nolan et al. 2014: 122). As a result, PUL discontent has been dispersed in three directions; at Sinn Fein, at the PSNI and at the criminal justice system (Nolan et al. 2014: 95). This polyvalent dispersal reflects disapproval of Sinn Fein involvement in the post-GFA state and post-Patten policing:

The Belfast Agreement [GFA] has allowed republicans to infiltrate every civic and public body as a result of the perverse notion of 'positive discrimination'. They now have their blood stained hands on the levers of justice and there is a clear cabal which runs throughout the PSNI, PPS and bodies such as... the parades commission. The PSNI work hand in glove with the PPS in pursuing these fruitless and political prosecutions, which, more often than not, end up as nothing more than Protestant bashing persecutions (Bryson 2015b).

The intricacies of the state-police power relationship and Sinn Fein involvement in these structures has given rise to claims that 'the PSNI are working on behalf of SF/IRA to take away our human rights and freedom of peaceful protests' (Belfast Daily 2013). Accordingly, if the anti-GFA Irish republican 'PSNI/RUC' narrative is one of too little substantive change then the PUL 'PSNIRA' narrative is one of too much change. Whereas the RUC were perceived as communal defenders of the PUL community, the PSNI are seen as antagonistic and hostile towards it (Halliday and Ferguson 2015). As such, when the PSNI were seen to be acting aggressively towards children and pensioners during the flag protests this was perceived as the innate sectarianism of Catholic officers working under the direction of Sinn Fein (Nolan et al. 2014). Similarly, this line of criticism also encompasses the criminal justice structures, with the appointment of two former solicitors who previously represented Sinn Fein President Gerry Adams to the roles of Attorney General and Director of the PPS causing 'the main pillars of justice' in the post-GFA state to be 'surrendered to the IRA' (Bryson 2013).

Despite strong assertions of a 'Sinn Fein/IRA' takeover of policing and the criminal justice system via 'critical engagement', this is not supported by statistical data. As Tomlinson (2012) notes, while the make-up of the PPS and the Courts and Tribunal Service is now more representative of what is often referred to as 'both communities', changes in the make-up of the police and the prison service have been less significant. The reality is, as O'Rawe (2010: 103) observes, that the PSNI are no more representative of Sinn Fein supporting working-class Nationalist communities than they are of workingclass PUL communities. Statistically speaking, 67\% of PSNI officers come from a Protestant background while $43 \%$ of PSNI officers previously served in the RUC-figures that rise to 75 and $49 \%$ respectively if PSNI 'civilian staff' are included. ${ }^{3}$ That the

3 This figures were contained in Freedom of Information Request F-2016-01238 made by the author in May 2016. 
PSNI retains a Protestant majority and a considerable RUC crossover element certainly tempers claims of a Sinn Fein purge of policing even if it does not change the PUL perception of post-Patten policing. Similarly, the PUL perception that socio-economic deprivation occurs on a sectarian basis that disadvantages them is also statistically unfounded. If anything, the figures on socio-economic deprivation suggest that Nationalist areas like West Belfast continue to suffer greater levels of deprivation than PUL areas like East Belfast (Nolan 2013: 85). The salience of highlighting these misconceptions is not to deny that PUL communities suffer from deprivation or to deny that they are politically policed but rather it is to demonstrate that what is articulated in simplistic sectarian 'winner-loser' terms is in fact more apposite for articulation through nuanced class-based and GFA position based terms.

\section{Discursive Commonality}

For all that competing discourses on political policing frame the matter differently through lived experiences of 'high policing' and 'low policing' and ideologised notions of too little and too тисh change, there is discursive commonality nonetheless. Both assume a starting ideological premise that political policing is primarily directed inwards. Through tackling spoiler violence and increased public disorder, the PSNI have been drawn into confrontation with both post-GFA 'outsider' constituencies (Topping 2015: 158). This has caused natural comparisons of how each purported threat is policed. In the North of Ireland, the historic trend was one of juxtaposing RUC violence exercised against Nationalist demonstrators with the restraint it showed when policing loyalist protestors (Mulcahy 2013: 142). Each post-Patten discourse therefore positions the 'ingroup' as the primary victims of political policing and as the bete noir of the post-GFA political order. Every act of political policing against 'us' is compared with every inaction against 'them'. Irish republicans, for example, compared the case of political activist Stephen Murney who was held on remand for over a year relating to (later withdrawn) 'terrorism' charges on the basis of having band uniforms and stencils with that of a loyalist who received two years probation and community service for planting explosives (Sovereign Nation 2014). Likewise, PUL communities complained of a 'two-tiered, politically-motivated policing system' after the PSNI discharged CS spray during a loyalist band parade yet failed to intervene at an Irish republican event involving masked men days earlier (Belfast Telegraph 2016). These claims demonstrate that heightened politicisation and localised peculiarity can temper Brogden's (2005) observation that because policing is done to someone on someone else's behalf what is fair for some will be unfair to others. When 'high policing' subjects 'us' to 'anti-terror' provisions but not 'them' or, conversely, when 'low policing' aggressively batons 'us' but not 'them', political policing is seen to operate along biased lines.

Notwithstanding this, political policing discourses are now sophisticated enough to move beyond a simplistic 'we get politically policed and they don't' paradigm. Narratives converge on several key points that locate the matter within the realm of the post-GFA state power play. Notable in both discourses, for example, is a structuralist understanding that implicates the wider criminal justice system in the silencing of opposition to the postGFA political order. One loyalist appearing in court on a flags protest charge asserted:

When you enter a Northern Ireland courtroom you enter a sham. A farcical system designed to protect the peace process... when you sit in the dock... there are two 
things that are certain. You will have been charged by the PSNI (who are now accountable to a policing board which contains convicted IRA terrorists) and you will be being prosecuted by the Public Prosecution Service (which is headed up by the former solicitor of choice for the IRA, Barra McGrory QC) (Bryson 2015a).

Echoing this structuralist interpretation of political policing, an Irish republican argued that it was a convoluted process involving:

The internment of republican activists, the recruitment of vulnerable working class people as informers and the manipulation of the judicial system in conjunction with corrupt people such as Barra McGrory the Director of Public Prosecutions... in order to put opponents of the state behind bars by any means necessary (Interviewee B, June 2013).

Although these accounts are still somewhat reflective of particular ideological viewpoints and responses to Sinn Fein 'critical engagement', there is nonetheless a common structuralist interpretation that attributes political policing to the machinations of a criminal justice system trying to suppress political dissent. By moving beyond the arresting officer or the officer wielding a baton, these views substantiate Reiner's observation on policing being a process by demonstrating how the traditional legitimacy politics that besieged the criminal justice system during the conflict have persisted during the transition-albeit now articulated in terms of fault lines relative to positions on the post-GFA state rather than ethno-nationalist allegiance per se.

Accordingly, this has seen tentative acceptance that political policing is also foisted on others who disagree with the post-GFA status quo. For example, one Irish republican criticised the criminal justice system for encouraging the loyalist Steward brothers to turn states evidence, arguing that 'this stuff shouldn't happen in a so-called democratic society' (Interviewee D, June 2013). By the same token, one loyalist criticised the PPS for failing to charge those aligned to Sinn Fein while at the same time bringing "very convenient prosecutions against not only Protestants but also against anyone within the republican community who speaks out against the Sinn Fein peace process strategy' (Bryson 2015b). Evidently, then, more nuanced understandings of political policing that depart from traditional interpretations in the North of Ireland have now emerged. Common convergence that moves beyond particularist ideological standpoints can be seen in a shared view that political policing is the means by which the expression of legitimate opposition to the postGFA state is curtailed. Moreover, there is a shared belief that those involved in legitimate and peaceful protest have been targeted in a bid to silence them. Flags protestor Willie Frazer complained that his arrest and subsequently protracted prosecution which had little chance of securing a conviction was a crude attempt to 'keep me silent' (Newsletter 2013). A similar logic is threaded through the synopsis that the arrest and subsequent release without charge of an Irish republican political activist who was questioned 'about organising peaceful protests' was designed 'to silence not alone opposition to British Rule in Ireland but to attempt to portray that people's right to freedom of expression and freedom to protest against the violation of human rights as illegal' (Derry 32CSM 2012).

This point is far from redundant but is in fact operative to understanding the process of political policing and the discourses of those subjected to it. After all, it is only by drawing disenfranchised sections of society into the criminal justice system on the mere basis of their disenfranchisement that the space for political debate and dissent is shut down through ensuring those aggrieved will not articulate or express their grievances for fear of arrest or targeting (Hillyard 1993). This has particular ramifications in post-GFA NI where 
the failure to deliver the 'peace dividend' has created a climate conducive to legitimate political opposition and peaceful protest yet a reality whereby:

If you have a belief and a political conscience to get out and fight and lobby and demonstrate and protest against that [post-GFA neoliberalism and political policing]... well then you are in for some special repressive treatment. Maghaberry [prison] awaits you (Interviewee J, October 2013).

The cumulative effect of the above is that while different ideological views of the postGFA state and post-Patten policing are by no means decommissioned, understandings and interpretations rooted in more nuanced terms vis a vis political positions relative to the post-GFA state are emerging. Commonality lies not in sharing ethno-nationalist infused ideological understandings of post-reform policing but in joint recognition of the structuralist dimensions of political policing and its relation to the protection of a postGFA status quo that continues to fail previously excluded communities still mired in socioeconomic deprivation.

\section{Conclusion}

Despite Patten reform and the subsequent 2007 endorsement of policing and criminal justice bodies by Sinn Fein, the issue of policing has not been resolved in post-GFA NI (O'Rawe 2010). As evidenced throughout this article, claims of political policing are as relevant now as they were at any time preceding or during the conflict. On one level the core substance of political policing discourses has arguably remained the same as it always was; it is a structuralist matter derived from the desire to protect the state at all costs and to suppress any political dissent. This is, of course, the same logic that pervaded criticism of the policing of civil rights demonstrations in the late 1960's (Mulcahy 2013: 27-29). The premise of state-police power relations has therefore remained constant, this aspect offering little departure from insights made in existing critical criminological literature on policing in NI.

What has changed, however, is how the state and the status quo being protected are interpreted and represented. The post-GFA state and post-Patten police force are markedly different to those traditionally associated with political policing discourses in the North of Ireland. Increased Nationalist involvement in the post-GFA state and post-Patten policing, as spearheaded by Sinn Fein, has conditioned political policing discourses by somewhat paradoxically feeding into but also moving beyond particular ideologised interpretations; it underpins dichotomous views of too little fundamental reform to a colonial police force and too much change of a historically protective police force but it also allows for commonality vis a vis positions relative to the post-GFA state to emerge. This commonality reflects class-based, rather than strictly ethno-nationalist, disillusionment with the postGFA state and its failure to adequately address structural exclusion and socio-economic deprivation. Where ethno-nationalism was once the most obvious policing fault line in the six counties, today it appears to be one falling along whether communities have 'moved on' with post-conflict transition or been 'left behind' by the process. The binaries of having 'moved on' or been 'left behind' are admittedly complex and involve an interplay between ideological views, class-based positions and lived experience of the post-GFA state, postPatten policing and Sinn Fein 'critical engagement'. While the importance of being politically policed specifically as an Irish republican or member of the PUL community has 
not become totally irrelevant, there is nevertheless acceptance that being against the postGFA state is the now underlying premise for post-Patten political policing across the board. Political policing discourses are now considerably more nuanced in that they no longer represent the matter in an exclusivist way attuned to traditional ethno-nationalist interpretations but instead exhibit an understanding of structuralist dimensions, class-based positions and 'dissidence' that transcend historic understandings of the matter.

Open Access This article is distributed under the terms of the Creative Commons Attribution 4.0 International License (http://creativecommons.org/licenses/by/4.0/), which permits unrestricted use, distribution, and reproduction in any medium, provided you give appropriate credit to the original author(s) and the source, provide a link to the Creative Commons license, and indicate if changes were made.

\section{References}

Albrecht, S. L., \& Green, M. (1977). Attitudes towards the police and the larger attitude complex: Implications for police-community relationships. Criminology, 15(1), 67-86.

BBC. (2015). Northern Ireland 'bringing up the rear' on fuel poverty, 25 March. http://www.bbc.co.uk/ news/uk-northern-ireland-32037850. Accessed 4 May 2016.

Becker, H. (1963). Outsiders: Studies in the sociology of deviance. New York: Free Press.

Belfast Daily. (2013). Revealed: UPF break off contact with PSNI As Frazer charged and Bryson arrested, 28 February. http://www.belfastdaily.co.uk/2013/02/28/revealed-upf-break-off-contact-with-psni-asfrazer-charged-and-bryson-arrested/. Accessed 2 May 2016.

Belfast Live. (2015). PSNI used stop and search powers more than 4,500 times in North Belfast figures show, 27 August. http://www.belfastlive.co.uk/news/belfast-news/psni-used-stop-search-powers9942941. Accessed 2 May 2016.

Belfast Telegraph. (2016). Loyalists meet PSNI over 'two-tier policing' in wake of Orange Order Ormeau parade CS spray debacle, 6 April. http://www.belfasttelegraph.co.uk/news/northern-ireland/loyalistsmeet-psni-over-twotier-policing-in-wake-of-orange-order-ormeau-parade-cs-spray-debacle-34603064. html. Accessed 3 My 2016.

Blackbourn, J. (2013). The UK's anti-terrorism laws: does their practical use correspond to legislative intention? Journal of Policing, Intelligence and Counter Terrorism, 8(1), 19-34.

Brewer, J. (2010). Peace processes: A sociological approach. Cambridge: Polity Press.

Brewer, J., \& Magee, K. (1991). Inside the RUC: Routine policing in a divided society. Oxford: Oxford University Press.

Brodeur, J. (1982). High policing and low policing: Remarks about the policing of political activities. Social Problems, 30(5), 507-520.

Brodeur, J. (2007). High and low policing in post-9/11 times. Policing, 1(1), 25-37.

Brogden, M. (1982). The Police: Autonomy and consent. London: Academic Press.

Brogden, M. (2005). 'Horses for courses' and 'Thin Blue Lines': Community policing in transitional societies. Police Quarterly, 8(1), 64-98.

Bryce, C. (2013). Back to armed struggle? The Dissidents Analysed. Irish Marxist Review, 2(5), $25-45$.

Bryson, J. (2013). Larkin and McGrory-The justice sell out 'deal', 8 October. http://jamiebryson.blogspot. co.uk/2013/10/larkin-and-mcgrory-justice-sell-out.html. Accessed 2 May 2016.

Bryson, J. (2015a). Barra McGrory, Sinn Fein and the IRA!. Long Kesh Inside Out, 3 March. http://www. longkeshinsideout.co.uk/?p=3071\&wprptest2=0. Accessed 2 May 2016.

Bryson, J. (2015b). Political case against YCV a warning to us all. Long Kesh Inside Out, 23 April. http:// www.longkeshinsideout.co.uk/?p=3140. Accessed 2 May 2016.

Choongh, S. (1997). Policing as social discipline. Oxford: Clarendon Press.

Committee on the Administration of Justice. (2012a). Still part of life here? A report on the use and misuse of stop and search/question powers in Northern Ireland. Belfast: Committee on the Administration of Justice.

Committee on the Administration of Justice. (2012b). The policing you don't see: Covert policing and the accountability gap five years on from the transfer of 'National Security' primacy to MI5. Belfast: Committee on the Administration of Justice. 
Coulter, C. (2014). Under which constitutional arrangement would you still prefer to be unemployed? Neoliberalism, the Peace process, and the politics of class in Northern Ireland. Studies in Conflict \& Terrorism, 37(9), 763-776.

Cray, E. (1972). The enemy in the streets. New York: Anchor.

Derry 32CSM. (2012). 32 CSM supports communities abused by PSNI, 6 June. http://www.derry32csm. com/2012/06/32-csm-supports-communities-abused-by.html. Accessed 2 May 2016.

Devlin-Mc Aliskey, B. (2016). Left behind by good friday. Jacobin, 21. https://www.jacobinmag.com/2016/ 04/bernadette-devlin-interview-derry-civil-rights-troubles-good-friday/. Accessed 2 May 2016.

Eirigi Newry. (2011). Political policing in Ireland ten years of the RUC/PSNI, 29 November. http:// eiriginewry.blogspot.co.uk/2011/11/political-policing-in-ireland-ten-years_29.html. Accessed 2 May 2016.

Ellison, G., \& Smyth, J. (2000). The crowned harp: Policing Northern Ireland. London: Pluto Press.

Goldsmith, A. (2005). Police reform and the problem of trust. Theoretical Criminology, 9(4), 443-470.

Hall, S., Critcher, C., Jefferson, T., Clarke, J., \& Roberts, B. (1978). Policing the crisis: Mugging, the state and law and order. London: MacMillan.

Halliday, D., \& Ferguson, N. (2015). when peace is not enough: The flag protests, the politics of identity \& belonging in East Belfast. Irish Political Studies. doi: 10.1080/07907184.2015.1084291.

Hearty, K. (2016). How the 'suspect community' became 'critical engagers': the (re)framing of the Irish republican narrative on policing in Northern Ireland. Irish Political Studies. doi:10.1080/07907184. 2016.1198322 .

Hepburn, J. R. (1977). Social control and the legal order: Legitimated repression in a capitalist state. Contemporary Crises, 1, 77-90.

Hillyard, P. (1993). Suspect community: People's experience of the prevention of terrorism acts in Britain. London: Pluto.

Hudson, B. (2003). Justice in the risk society. London: SAGE.

Irish Republican News, (2015). Figures confirm scale of PSNI harassment, 29 August. http://republicannews.org/current/news/2015/08/figures_confirm_scale_of_psni_.html\#.VydbUzArLIU. Accessed 2 May 2016.

Irish Republican News. (2016). Political policing of individuals and communities, 16 April. http:// republican-news.org/current/news/2016/04/political_policing_of_individu.html\#.VydYjDArLIU.

Jackson, R. (2007). Policing. In C. Ó. Brolcháin (Ed.), The politics of policing (pp. 5-20). Belfast: James Connolly Debating Society.

Jackson, A., \& Lyon, A. (2001). Policing after ethnic conflict: Culture, democratic policing, politics and the public. Policing: An International Journal of Police Strategies \& Management, 24(4), 563-584.

Kelly, B. (2012). Neoliberal Belfast: Disaster ahead? Irish Marxist Review, 1(2), 44-59.

Kettle, M. (1980). The politics of policing and the policing of politics. In P. Hain (Ed.), Policing the Police (pp. 9-62). London: John Calder.

Loader, I., \& Mulcahy, A. (2003). Policing and the condition of England: Memory, politics and culture. Oxford: Oxford University Press.

Long, S. (2015a). Unheard voices: East Belfast's 'Undesireable' working class. The Pensive Quill, 23 May. http://thepensivequill.am/2015/05/unheard-voices-east-belfasts.html Accessed April May 2016.

Long, S. (2015b). Is it time to consider giving loyalists special group rights?. Slugger O'Toole, 17 November. http://sluggerotoole.com/2015/11/17/soapbox-is-it-time-to-consider-giving-loyalistsspecial-group-rights/. Accessed 4 May 2016.

Mac Ionnrachtaigh, F. (2013). Language, resistance and revival: Republican prisoners and the Irish Language in the North of Ireland. London: Pluto Press.

MacGinty, R., \& du Troit, P. (2007). A disparity of esteem: Relative group status in Northern Ireland after the Belfast agreement. Political Psychology, 28(1), 13-31.

McDowell, S., Braniff, M., \& Murphy, J. (2015). Spacing commemorative-related violence in Northern Ireland: Assessing the implications for a society in transition. Space and Polity, 19(3), 231-243.

McGarry, J., \& O'Leary, B. (1999). Policing Northern Ireland: Proposals for a new start. Belfast: Blackstaff Press.

McLaughlin, E. (2007). The new policing. London: SAGE.

McVeigh, R. (1994). It's part of my life here: The security forces and harassment in Northern Ireland. Committee on the Administration of Justice): Belfast.

McVeigh, R. (2015). No one likes us, We don't care: What is to be (Un)done about ulster protestant identity? In T. Burgess \& G. Mulvenna (Eds.), The contested identities of ulster protestants (pp. 113-133). Hampshire: Palgrave MacMillan.

Mulcahy, A. (2013). Policing Northern Ireland: Conflict, legitimacy and reform. London: Routledge. 
Mulvenna, G. (2015). Labour aristocracies, triumphalism, and melancholy: Misconceptions of the protestant working-class and loyalist community. In T. Burgess \& G. Mulvenna (Eds.), The contested identities of ulster protestants (pp. 159-176). Hampshire: Palgrave MacMillan.

Murphy, J. (2013). Policing for peace in Northern Ireland: Change, conflict and community confidence. London: Palgrave MacMillan.

Neocleous, M. (2000). The fabrication of social order: A critical theory of police power. London: Pluto.

Neocleous, M. (2014). War power, police power. Edinburgh: Edinburgh University Press.

Newsletter. (2013). Frazer: PSNI are stalling my trial to silence me, 19 July. http://www.newsletter.co.uk/ news/northern-ireland-news/frazer-psni-are-stalling-my-trial-to-silence-me-15300900\#ixzz47UpkBZqj. Accessed 2 May 2016.

Nolan, P. (2013). The Northern Ireland peace monitoring report: Number two. Belfast: Community Relations Council.

Nolan, P., Bryan, D., Dwyer, C., Hayward, K., Radford, K., \& Shirlow, P. (2014). The flag dispute: Anatomy of a protest. Belfast: Community Relations Council.

O'Rawe, M. (2010). Security sector reform and identity in divided societies: Lessons from Northern Ireland. In P. Arthur (Ed.), Identities in transition: Challenges for transitional justice in divided societies (pp. 87-117). Cambridge: Cambridge University Press.

Reiner, R. (2010). The politics of the Police (4th ed.). Oxford: Oxford University Press.

Scraton, P. (1985). The state of the police. London: Pluto Press.

Scraton, P. (2007). Power, conflict and criminalisation. London: Routledge.

Shirlow, P. (2012). The end of Ulster loyalism?. Manchester: Manchester University Press.

Sovereign Nation. (2014). Business as usual for Britain in Ireland. February/March.

Steenkamp, C. (2005). The legacy of war: Conceptualizing a 'Culture of Violence' to explain violence after peace accords. The Round Table, 94(379), 253-267.

The Plough \& The Stars. (2016). Political policing continues, 19 January. https://irishredstar.wordpress.com/ 2016/01/19/political-policing-continues/. Accessed 2 May 2016.

Tomlinson, M. (2012). From counter-terrorism to criminal justice: Transformation or business as usual? The Howard Journal of Criminal Justice, 51(5), 442-457.

Topping, J. (2015). Accountability, policing and the Police Service of Northern Ireland: local practice global standards? In S. Lister \& M. Rowe (Eds.), Accountability of policing (pp. 150-171). Oxon: Routledge.

Weitzer, R. (1995). Policing under fire: Ethnic conflict and police-community relations in Northern Ireland. New York: State University of New York. 